\section{Osler's node}

\author{
Taro Shimizu, Yasuharu Tokuda
}

Emory University, Atlanta, Georgia, USA

\section{Correspondence to} Taro Shimizu,

shimizutaro7@gmail.com

\section{DESCRIPTION}

A 49-year-old man presented with a 3-day history of fever. Three days back, he experienced shaking chill. He tried acetaminophene, but the fever rose up to $39^{\circ} \mathrm{C}$. One day back, he noticed several painful dark spots on both of his palms. He denied any similar event in the past, and also denied any sick contact, intravenous drug use or recent travel. On examination, painful violaceous nodules were palpable on his left thenar eminence (figure 1) and conjunctival haemorrhages were observed (figure 2). Janeway lesions and sublingual splinters were not found. Heart auscultation revealed a mild regurgitant murmur over the mitral area. Transthoracic ECG revealed vegetation of the mitral valve (figure 3, arrow head) with mild mitral regurgitation. Blood culture revealed Streptococcus viridans from three bottles. Additional history revealed he visited a local dentist and had tooth extraction 2 weeks prior to the onset of the symptoms. Fever subsided 5 days after the initiation of intravenous penicillin G. On day 9, his symptoms resolved and the nodes resolved (figure 4).

We concluded that the patient's infective endocarditis was attributed to the dental procedure, allowing Streptococcus to drain into the bloodstream.

Osler's node, first described by William Osler, ${ }^{1}$ is associated with chronic (subacute) bacterial endocarditis. Cultures of Osler's node have generally been negative. ${ }^{2}$ The culture of the nodes in this case was negative. ${ }^{2}$ Although Osler's node is

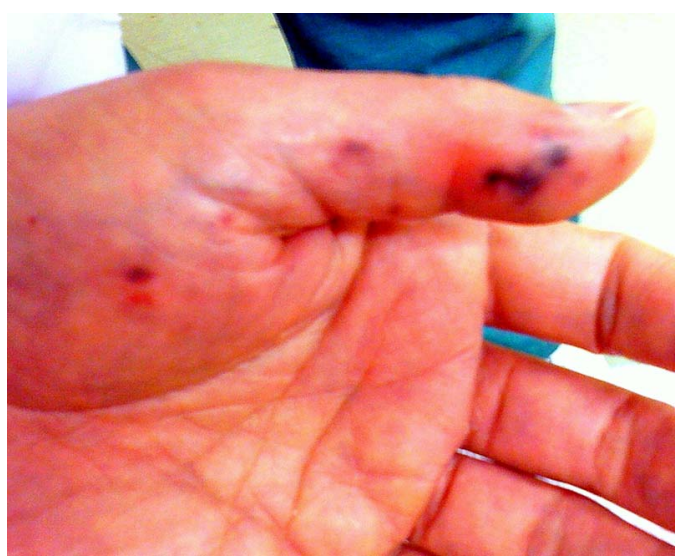

Figure 1 Palpable and painful violaceous nodules left thenar eminence.

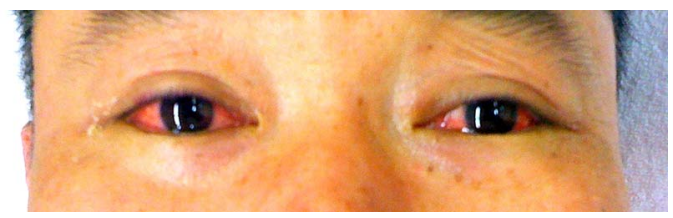

Figure 2 Conjunctival haemorrhages.

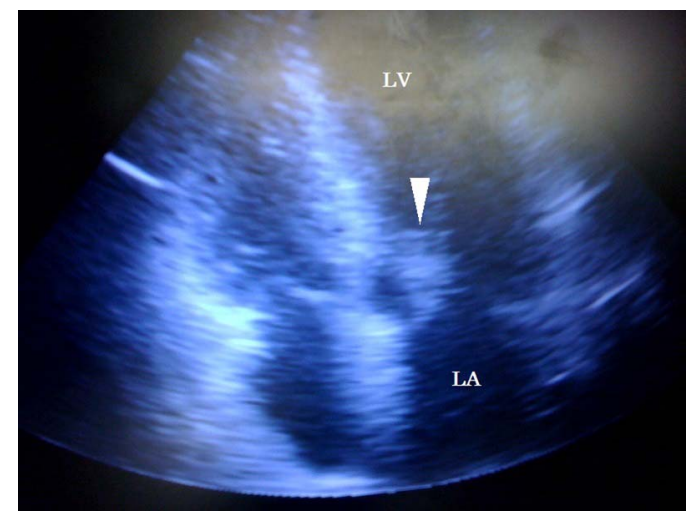

Figure 3 Vegetation of the mitral valve by transthoracic ECG.

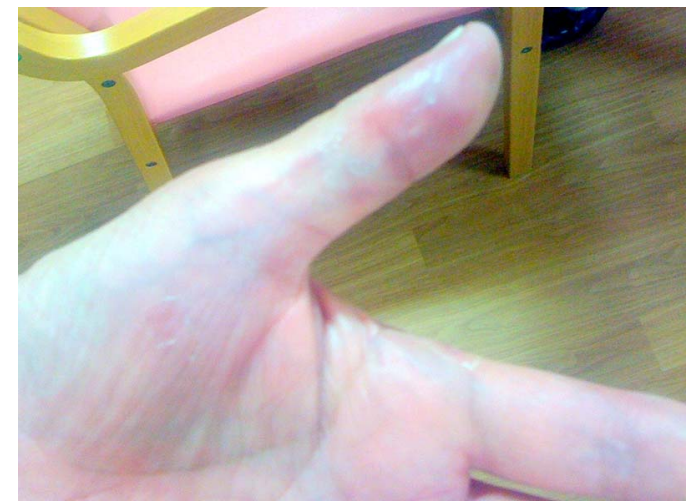

Figure 4 Resolved nodes after the treatment.

reported to occur in lupus, they are strongly suggestive of bacterial endocarditis. ${ }^{3}$

\section{Learning points}

- Osler's node is associated with chronic (subacute) bacterial endocarditis.

- Careful inspection on hands with fever patients can reveal evidence of bacterial endocarditis.

Competing interests None.

Patient consent Obtained.

Provenance and peer review Not commissioned; externally peer reviewed.

\section{REFERENCES}

1 Osler W. Chronic infectious endocarditis. Q J Med 1909;2:219-30.

2 Farrior JB, Silverman ME. A consideration of the differences between a Janeway's lesion and an Osler's node in infectious endocarditis. Chest 1976;70:239-43.

3 Libman E, Friedberg CK. Subacute bacterial endocardial diseases of the heart, blood vessels, and blood. In: Christian H. The oxford medicine. 2nd edn. New York: Oxford University Press, 1949;2:34-6. 
Copyright 2013 BMJ Publishing Group. All rights reserved. For permission to reuse any of this content visit http://group.bmj.com/group/rights-licensing/permissions.

BMJ Case Report Fellows may re-use this article for personal use and teaching without any further permission.

Become a Fellow of BMJ Case Reports today and you can:

- Submit as many cases as you like

- Enjoy fast sympathetic peer review and rapid publication of accepted articles

- Access all the published articles

- Re-use any of the published material for personal use and teaching without further permission

For information on Institutional Fellowships contact consortiasales@bmjgroup.com

Visit casereports.bmj.com for more articles like this and to become a Fellow 